\title{
Philosophy of Economics and Management: Youth Participation in Family Business and National Economy
}

\author{
ZUZANA HORČIČKOVÁ ${ }^{1}$, NERIJUS STASIULIS² \\ ${ }^{1}$ Faculty of Economics, Technical University of Liberec, Studentská 2, 46117 Liberec, Czech Republic \\ ${ }^{2}$ Department of Philosophy and Cultural Studies, Faculty of Creative Industries, Vilnius Gediminas Technical University, Trakų St. 1, \\ 01141 Vilnius \\ Email: nerijus.stasiulis@vgtu.It; zuzana.horcickova@tul.cz
}

\begin{abstract}
The aim of the present paper is to reconcile a philosophical reflection on the role of the family as a communitarian entity in the business environment based on the individualistic principle and practical research aimed at identifying young people's attitudes towards their involvement in family business. Respondents of the research were students of the final years of secondary schools, tertiary professional schools and vocational schools in the Liberec Region. The family is treated from the ethical point of view as well as in terms of political and economic philosophy as a suitable environment to shape economic attitudes in young people that are not restricted to a merely 'economist' form of rationality and as able to play an important part in a properly working state economy. The practical research shows that a young person's intention to work in the family business depends on whether they are involved in it already during their studies.
\end{abstract}

Keywords: ethics, family business, participation, philosophy of economics, rationality, young person

\section{INTRODUCTION}

Many authors and organisations consider family businesses to be an important form of business entities that contribute to the national economy (e.g.: EESC 2015; Zellweger 2017; AMSP CR 2018a). One important issue within this type of business is succession, i.e. the transfer of the business from one (older) generation to the next (younger) generation. For these purposes, a young person is defined using the definition adopted by the Ministry of Education, Youth and Sports of the Czech Republic, hereinafter MSMT CR, which defines a young person as a person aged 15 to 29 years (MSMT CR 2017).

The aim of this paper is to reflect on the philosophical premises of economy which may liberate or hinder the existence of family businesses and to identify young people's attitudes concerning their involvement in family business using descriptive statistics methods, in particular by analysing dependencies. This paper, thus, addresses the key economic notion of 
individual rational pursuit and localizes it in a broader context of possible rationalities with respect to communitarian or universalistic values and then, from the practical point of view, addresses different forms of young people's involvement in family business and their interrelations, i.e. whether young people's involvement in business during their studies affects their motivation to later work in the family business and subsequently take it over.

\section{THEORETHICAL BACKGROUND}

The issue of family business can be viewed from the viewpoint of moral, economic or political philosophy. It plays an important role in national economies and is subject to economic and sociopolitical policies as well as to different possible philosophies that guide economies and business activity. These policies and philosophies are largely based on liberal-individualistic principles and strategies which are substantiated by the notion of rational pursuit of individual self-interest. If economic activity is basically individualistic, what is its relation to the family which is a communitarian entity? What is the role of family business in economy?

The premise of the rational pursuit of individual self-interest not only shaped economic order and substantiated political liberalism, but has lately changed individual and socio-political consciousness so that both experts and individuals tend to think of economico-political subjects as essentially atomistic homini oeconomici who extend the 'economic logic' of market to all spheres of life, including family and politics. Economists have devised theories that describe family as internally structured by market relations of individual rational pursuit.

In broader terms, rationality, or reason, is in this type of theory defined not as the activity of grasping 'eternal ideas' but instrumentally, i. e. as a means-to-ends rationality. The separation of objective and instrumental types of reason was, for instance, marked by Horkheimer $(1947,1974)$. The contrast between the two is at the heart of many current social and philosophical debates as well as debates in political science (Stewart 1995: 57-59).

The more substantial criticism of instrumental reason asserts that the instrumental account of reason alone cannot explain the emergence of institutions and procedures. Hegel has provided a substantial criticism of a merely-economic reason which, however, allows for a crucial and positive role for liberal economy and economics (see Greer 1999). It accommodates both instrumental and 'eternal' reason and also sees an importance of the family. According to his dialectical scheme, modern economy is based on individual particularization through different unique lifestyles that are molded by satisfying a particular set of extra-natural needs. This particularization is an expression of individual freedom. Yet, this particularization (individual rational pursuits of self-interest) gives rise to economic laws (described by classical liberal economics) through unintended results of individual instrumentally-rational actions. The laws are universal, but merely in terms of intellect (Verstand), and thus (like Newtonian laws of nature) are blind, not willed or desired by anyone; therefore, Hegel claims that true universality is the one conceived in terms of reason as Vernunft where the dialectical opposition of universality and particularity is sublated and freedom is realized through freely-willed legislation and institutions of a political state. Individuals separated from their natural families to engage in the free market but the utmost realization of freedom transcends economic relations and takes place in the political sphere; thus, the family serves as a primary model of universality, which is later repeated in a higher order, in the political sphere. Importantly, Hegel asserts that social problems (such as poverty) should not be solved by implementing social policies (based on universal laws of economics) as that would counter the very individual freedom and independence which is the gist of the free market. But freedom is not 
contradicted by freely associating into 'corporations' which Hegel sees as akin to the family in terms of universality and a mediator between the family and the political state (Hegel 2003: $\$ 225)$. True freedom and dignity cannot be achieved merely individually through rational self-pursuit, although the latter is a necessary moment on the 'way' to freedom.

Another important argument against understanding reason as merely instrumental rests on the fact that people's choices are not 'mere means' but significantly affect their understanding of their goals (as in the Totts effect, see Stewart 1995: 68). Hence, choosing a family business as opposed to some other sort should not be viewed merely in terms of its efficacy but also in terms of molding individuals who have made that choice. Family, as the first school of universality which is not opposed to freedom, is useful in molding the necessary habits and points of view in citizens.

Also, family business serves as an exemplary model of organization. Recently, many have expressed the view - influenced by economic theorists aimed at neutral application of rationality - that organization should be quite contrary to the family business model, i. e. as depersonalized as possible. While, in fact (Petrosyan 2018), depersonalization does not raise the level of management but merely technicalizes it and excludes the crucial elements of emotion, volition and the unconscious. People get detached from their organizations and become merely tame implementers of 'objective' instructions. Whereas successful management requires quite the opposite: self-reliant, creative workers, groping with their tasks independently with a wide range of free problem solving. As business norms do not absolve one from his or her responsibility for the Other (Tajalli, Segal 2018), one should seek to implement business norms compatible with the 'human' factor, and family business is a good model.

The benefits of family business stem among other things from the concept of intergenerational transfer of family business, which gives this type of business good long-term prospects. Know-how transfer, patient capital (the investment is profitable in the long run) or the credibility of the company (Koráb et al. 2008; EESC 2015; Zellweger 2017) - all that results from the long-term focus of family businesses. This long-term nature is due to the fact that there is an effort to transfer the successfully built family business to the next generation.

Each country has its own specificities, which is why certain aspects of family businesses may vary in different economies (Machek 2017). For historical reasons, there are a large number of family businesses in the Czech market that are managed by the first or second generation of the family and it is necessary to address the issue of succession (Bednaŕík et al. 2014; Petrů 2018). The results of the initial primary survey carried out within the Northeast NUTS2 unit showed that most respondents from the ranks of family businesses did not currently consider it a primary objective to pass the business on to the next generation (Horčičková 2017). This is viewed as a problem, because succession is a critical point for family businesses, and statistics unfortunately show that more than $2 / 3$ of family businesses do not survive the first handover process (Luan et al. 2017).

The transfer of a family business can be done within (i.e. intra-family succession) or outside the family. Intra-family succession is a long-term planning and management process that involves factors ranging from the involvement of children in the business from a relatively young age to a plan for transferring ownership interests. Therefore, this process does not begin when the older generation decides to step down from the business, but rather it already begins when the potential successors are still children (Petrů 2018) In the process, the primary question is the willingness of the successor to take over the family business (Zellweger 2017). 
Zellweger (2017) states that family members generally do not have a strong interest in taking over the family business. He also mentions that fewer than $23 \%$ of prospective successors among the respondents of the GUESSS global survey (examining the entrepreneurship of university students) were considering taking over the business. PricewaterhouseCoopers (2012) also states that the key issue in a handover is the preparation and motivation of the successor.

According to Pablo-Lerchundi et al. (2015), the career path of children is heavily influenced by their parents. Children of entrepreneurs tend towards entrepreneurship more than children of employed persons. On the other hand, Zellweger et al. (2011) claim that some children who have an entrepreneur in the family want to be employed because they have witnessed the hardship and personal sacrifices their parents had to make because of their business. Murphy et al. (2015) argue that involving the young generation in family business strongly influences their choice of profession. The reason for this involvement, even at a later age, is to help the family and the family business. If family members decide to be employed outside the family business, they still remain involved in the family business and help the business in those areas in which they are employed. This involvement of the next generation in family business through help may, in turn, play a positive role in terms of their willingness to become successors. Rydvalová et al. (2015) make a similar claim, namely that the best chance of making the second generation interested in taking over a family business is to guide this generation towards succession from early childhood, i.e. to cultivate an interest in participating in the family business.

In order to successfully pass the company on to the next generation, the successor should already have some experience in the business, such as an understanding of products and the market, knowledge of key customers, competitors and suppliers, and last but not least, an understanding of the company's finances (PricewaterhouseCoopers 2015; Kenyon-Rouvinez 2016). However, according to PricewaterhouseCoopers (2015), the successor generation worked in the family business in only $29 \%$ of cases (Central and Eastern Europe). At round-table discussions organised by the Association of Small and Medium-Sized Enterprises and Crafts of the Czech Republic (hereinafter AMSP CR), members of the successor generation in Czech family businesses who have already taken over the business indicated that they had grown up in the business environment since early childhood and that the company had been another sibling to them. Members of the next successor generation, who do not yet run the business, stated that as successors they should work alongside their parents for some time. In most cases, they have worked in the business from a certain age on a part-time basis or as seasonal help (Petrů 2018).

The GUESSS survey, which was conducted in the Czech Republic in 2016, indicated that $73 \%$ of respondents (students of Czech universities) do not work for their parents' business, and there is a rather negative attitude towards taking over family business (Rydvalová et al. 2017a).

Other surveys concerning family business are carried out annually by AMSP CR among small and medium-sized family businesses up to 250 employees. These surveys showed that about $50 \%$ of family businesses involved their children in the business (AMSP CR 2015, 2016). The most common age at which they become involved in the business ranges from 18 to 21 years, i.e. in approximately 33\% of cases (AMSP CR 2015, 2016). According to 25\% of them, the ideal age for the young generation to become involved in the business is $18-21$. The same percentage of respondents indicated an age range of 15-17 years, and also of less than 15 years (AMSP CR 2015). 
Based on the above, the following research questions (hereafter RQ) were formulated, addressing young people's involvement in business:

RQ (1a): Is there a connection between a young person's involvement in family business already during their studies and their subsequent intention to work in the family business?

RQ (1b): Does a young person's willingness to take over business in the future depend on their intention to work in the family business after completing their studies?

From the perspective of research into family business, it is first important to define this type of business. Each country or even organisation defines this concept differently. Therefore, it is important to realise that it is not always possible to compare the research results with other research addressing this topic. Given the differences between the various types of family businesses, the research questions RQ (2a) to RQ (2c) were asked:

RQ (2a): Does a young person's involvement in family business during their studies depend on the type of family business?

RQ (2b): Is a young person's intention to work in the business influenced by the type of family business?

RQ (2c): Is there a connection between the intention to take over the business in the future and the type of family business?

\section{METHODOLOGY}

In the Czech Republic, including the Liberec Region, neither the statistical office nor any other institution monitor the family-business activities of all business entities, even though this is the focus of interest of the European Economic and Social Committee (EESC 2015). Therefore, there is no database of family businesses and, in turn, the size of the statistical population is not known. For this reason, it is not possible to carry out random sampling to select respondents from family businesses within the Liberec Region and ask their potential successors aged 15-29 for the information needed. Due to legislative constraints (personal data protection) and the time and financial demands, it was also impossible to carry out a two-stage sample survey in which all young people aged 15-29 in the Liberec Region would be asked about family business and only then, on the basis of their responses, a sample survey comprising those with an identified family business would be examined. In the framework of this research, students of the final years of secondary schools (and tertiary professional schools) and vocational schools in the Liberec Region are considered to be the target group.

Given the specificities of the Czech environment, the definitions and types of family business used in this research have been borrowed from Rydvalová et al. (2017b). However, they have been simplified and adapted to a form comprehensible to the respondents. It was crucial that at least two family members were involved in the business. In the case of a family business corporation, emphasis was placed on the ownership interest held by the family, which is the connecting and dominant element of several definitions of family business (Rydvalová et al. 2016; Machek 2017). In order to prevent excluding family businesses owned by, e.g. two families, the definition includes corporations in which the family owns at least a $50 \%$ interest. For the purposes of this research, family businesses are considered to include:

(a) Family Business Corporation: A business corporation in which the family holds at least $50 \%$ ownership interest and in which 2 family members are involved, whether through work or ownership. 
(b) Family Enterprise: A family member does business as a physical (natural) person under the Trade Licensing Act or other laws, and at least 1 other family member helps without any contract/agreement.

(c) Family Agglomeration:

1) A family member does business as a physical person under the Trade Licensing Act or other laws, and at least 1 other family member helps pursuant to a contract/agreement;

2) Multiple family members do business as physical persons under the Trade Licensing Act or other laws and they cooperate.

In order to determine the attitudes of young people, the survey technique was chosen as the method of data acquisition, which is the most widespread way of obtaining information, especially in socio-economic areas. Eventually, $84.44 \%$ (38 out of 45 ) secondary and vocational schools and tertiary professional schools in the Liberec Region took part in the questionnaire survey.

The evaluation was done in the MS Excel and in the Statgraphics Centurion statistical programme. The evaluation was carried out using methods of descriptive statistics and also by analysing the dependence of selected variables. For missing data, the pairwise deletion method was used, i.e. a method where only those rows are omitted that concern at least one of the variables in the calculations currently being performed.

Due to the analysis of categorical variables, the Chi-square independence test in a contingency table was used to evaluate the dependence analysis within the research questions. All tests were performed at a significance level of $\alpha=5 \%$.

Given the amount of content, the paper focuses on analysing the basic variables obtained from the questionnaire survey. Here, the results of the analysis are provided for the following 4 variables:

- Family business type: the variable takes 6 possible values (a, b, c1/c2, see above, 'I do not know', 'not specified'). When identifying the type of family business, the respondents could also use the 'I do not know' option in order to prevent distorting data when unsure. This variable will also be referred to as 'FBT'. The data analysis will only work with the values a, b, c (c1 and c2 will be merged).

- The student's involvement in family business during their studies: the variable takes two possible values (YES, NO); this variable will also be referred to as 'IDS'.

- The student's intention to work in the family business after completing their studies: the variable takes three possible values (YES - immediately after my studies, YES - I want to work somewhere else first, NO). In the dependence analysis, the YES-type answers are merged and the variable thus takes 2 possible values (YES, NO); this variable will also be referred to as 'IW'.

- The student's willingness to take over the business in the future - the variable takes two possible values (YES, NO); this variable will also be referred to as 'WT'.

\section{RESULTS}

This chapter includes the research results. First, an evaluation is carried out using descriptive statistics methods, and subsequently, an analysis of the dependencies of these variables is carried out.

A total of 1951 students aged 17-29 who meet the definition of a young person according to the MSMT CR (2017) participated in the survey. 609 respondents have a family business in their families, which represents $31.2 \%$ of all respondents. Seven of these respondents were excluded from the evaluation because their questionnaires were incomplete. 
Distribution of respondents according to different family business types consists of 568 observations. The remaining 34 respondents did not know or, in a single case, did not specify the family business type. For a more detailed description of the different types, see above. The most common type of family businesses is a Family Enterprise, which was indicated by $48 \%$ of the respondents. 31\% of the students had a Family Business Corporation in their family. An Agglomeration is the least frequent, accounting for $21 \%$ of the overall frequency distribution. Of these $21 \%$, the (c1) family business type accounts for nearly $60 \%$, as compared to $40 \%$ for (c2).

The research (602 observations) shows that $38.54 \%$ of the respondents are already involved in the family business during their studies, as opposed to $61.46 \%$ who do not help in the business. More than $70 \%$ of the students said they did not want to work in the family business after completing their studies. Of the $28 \%$ respondents who want to work in the family business, $50 \%$ want to start working in the family business immediately after completing their studies. The other half of the students want to work somewhere else first, and return to the family business later.

Interestingly, $2.16 \%$ of all respondents are neither involved in the business during their studies nor want to work there after completing their studies, yet they want to take it over in the future. By contrast, $2.49 \%$ of those students who are already involved in the family business during their studies and want to continue working there do not want to take over the business.

Dependency analyses were always carried out in two versions. One contains all data regardless of the respondent's relationship to the business owner (called 'All data'). The second part of the comparison then only considers the analysis of data where the owner of the family business was in a direct family relationship to the respondent, i.e. the student's parent(s) (called 'Only parents').

The Chi-square test showed that in all cases the P-Value $<0.05$, which is why the null hypothesis was rejected and the alternative hypothesis was accepted, i.e.:

RQ (1a): There is a connection between a young person's involvement in family business during their studies and their subsequent intention to work in the family business. However, in both cases ('All data' and 'Only parents') the Pearson coefficient points to a moderate to week dependence.

RQ (1b): The willingness to take over the business in the future depends on the young person's intention to work in the family business after completing their studies. Here, Pearson's R of $80.33 \%$ ('All data') and 79.82\% ('Only parents') shows a very strong direct dependence.

Additional dependency analyses addressed the research questions (2a) to (2c) focusing on a young person's participation in the business with respect to the family business type. For the research questions (2a) and (2b), the null hypothesis was not rejected. Neither the student's involvement in the family business nor their intention to work in the family business after completing their studies is dependent on the family business type. A very weak dependence was demonstrated for RQ (2c).

As to the frequency distribution of responses concerning the respondent's willingness to take over the family business depending on the family business type, there are no significant differences in the ratios between the grey and white areas for various family business types. Therefore, the dependence cannot be considered as significant. However, the strength and the direction of the dependence differ in the case of 'All data' and in the case of 'Only parents' data. In the former case, the likelihood of business takeover is greater for a Family Business Corporation. In the latter case, it is higher for a Family Agglomeration. 


\section{DISCUSSION AND CONCLUSIONS}

Approximately $30 \%$ of the students have a family business in their family. Almost half of these respondents have a Family Enterprise in their family. The higher proportion of business entities in the form of physical persons is understandable given the ratio of entrepreneurs in the Czech Republic - in the second quarter of 2018, the ratio was approximately 5:1 in favour of physical persons compared to legal persons (Ministry of Industry and Trade 2018a). This ratio may be due to the administrative demands associated with setting up a business corporation, as compared to doing business as a natural person. Another reason may be the more stringent criteria that define family business in the case of a Family Business Corporation.

Out of those respondents where a family business was identified, more than $72 \%$ do not want to take over the family business (66\% in the case of respondents where the family business is owned by their parents), and similar percentages are also found for the intention to work in the company after completing studies and the student's involvement in the business already during their studies. The results thus confirm the findings of Zellweger (2017) and Rydvalová et al. (2017a), i.e. the existence of a negative attitude among young people - in this case mainly students of secondary and vocational schools - towards family business succession. All of this reflects the internalization of individualistic premises of economics in the individual consciousness.

In learning to doubt the absolute truth of these premises, it is important to realise the futility of the distinction of means and ends as means chose already mold one's predisposition toward certain goals. Within RQ (1a), a dependence between the given parameters was assumed. Therefore, the hypothesis that if young persons are involved in the family business already during their studies, they plan to continue working in the business after completing their studies, was confirmed. As assumed, a strong dependence was also found for RQ (1b). If students want to work in the family business after completing their studies, they also most likely intend to take it over in the future. The results highlight the importance of young people's involvement in the business already during their studies, and especially after completing their studies. So, if owners of family businesses want to pass their business on to their family members in the future, they should above all try to motivate their intention to work in the business. In most cases, it is this intention that ensures their willingness to take over the family business.

In terms of the family business type, the respondents' willingness to take over the family business in the case of an 'Only parents' ownership proved to be higher for Family Agglomerations. As regards 'All data', the greatest interest in taking over the family business exists in the case of a Family Business Corporation. Therefore, if the family business is not owned by the respondent's parents, the likelihood that the student will be willing to take it over in the future is higher for a Family Business Corporation.

The issue of succession is crucial for the continuity of family business. According to the Family Business Institute (2018), only 30\% of family businesses survive succession from the first to the second generation, and even fewer from the second to the third generation. However, the willingness of the young generation to take over the family business is not the sole (sufficient) condition for the successful transfer and functioning of the family business but it is considered a basic condition for intra-family succession. The more fundamental assumptions concerned with the relation of universality and particularity with respect to economies and the place of family business in them should be taken into account to open the space for other-than-merely-individualistic rationalities. 


\section{ACKNOWLEDGEMENTS}

This article was written in the framework of SGS-EF-3300-21231 'Young Generation in Family Business in the Context of the Municipality', Faculty of Economics, Technical University of Liberec.

Received 1 October 2018

Accepted 19 December 2018

\section{References}

1. AMSP CR. 2015. Situace rodinných firem. Available at: https://amsp.cz/32-pruzkum-amsp-cr-rodinne-firmy/ (cited 22.08.2018).

2. AMSP CR. 2016. Specifika rodinného podnikání. Available at: https://amsp.cz/40-pruzkumamsp-cr-specifika-rodinneho-podnikani/ (cited 22.08.2018).

3. AMSP CR. 2017. Specifika rodinného podnikání. Available at: https://amsp.cz/48-pruzkum-specifikarodinneho-podnikani/ (cited 22.08.2018).

4. AMSP CR. 2018a. Tisková zpráva: Rodinné podnikání dostává zelenou. Available at: https://amsp.cz/ rodinne-podnikani-dostava-zelenou/ (cited 22.02.2018).

5. AMSP CR. 2018b. Výroční průzkum k trendìm rodinného podnikání. Available at: https://amsp. cz/58-pruzkum-amsp-cr-vyrocni-pruzkum-k-trendum-rodinneho-podnikani/ (cited 22.08.2018).

6. Bednařík, R.; Mikulka, M. 2014. "Nástup nové generace znamená pro rodinné firmy zlomové období: První vlna majitelů předává firmy”, Hospodářské noviny 228(1).

7. EESC. 2015. Rodinné podniky v Evropě jako zdroj budoucího růstu a lepších pracovních míst. Brusel: European Economic and Social Committee.

8. Family Business Institute. 2018. Succession Planning. Available at: https://www.familybusinessinstitute. com/consulting/succession-planning/ (cited 27.08.2018).

9. Greer, M. R. 1999. "Individuality and the Economic Order in Hegel's Philosophy of Right", Journal of the History of Economic Thought 6(4): 552-580.

10. Hegel, G. W. F. 2003. Elements of the Philosophy of Rights. Cambridge University Press.

11. Horčičková, Z. 2017. "Succession and Other Goals of Family Businesses: A Study of Selected Czech SMEs", in Proceedings of the 12th International Conference: Liberec Economic Forum 2017. Liberec: Technical University of Liberec, 499-505.

12. Horkheimer, M. 1947. Eclipse of Reason. Oxford University Press.

13. Horkheimer, M. 1974. Critique of Instrumental Reason. Continuum.

14. Kenyon-Rouvinez, D.; Ward, L. 2016. Rodinná firma: Jak vybudovat, úspěšně vést a předat rodinný podnik. Brno: Barrister \& Principal.

15. Koráb, V.; Hanzelková, A.; Mihalisko, M. 2008. Rodinné podnikání. Brno: Computer Press.

16. Luan, C.-J.; Chen, Y.-Y.; Huang, H.-Y.; Wang, K.-S. 2017. "CEO Succession Decision in Family Businesses - A Corporate Governance Perspective", Asia Pacific Management Review 23(2): 130-136. Available at: https://doi.org/10.1016/j.apmrv.2017.03.003

17. Machek, O. 2017. Rodinné firmy. Praha: C. H. Beck.

18. MSMT CR. 2017. Mládež v $\check{C} R$. Available at: https://www.msmt.cz/mladez/mladez-v-cr (cited 15.08.2017).

19. Ministry of Industry and Trade. 2018a. Number of Entrepreneurs - Natural Persons - and Trade Licenses According to Sex. Available at: https://www.mpo.cz/en/business/licensed-trades/statistical-data-onentrepreneurs/revize-1-en-pocty-podnikatelu-a-zivnosti-dle-kraju--226392/ (cited 27.08.2018).

20. Murphy, L.; Lambrechts, F. 2015. "Investigating the Actual Career Decisions of the Next Generation: The Impact of Family Business Involvement", Journal of Family Business Strategy 6(1): 33-44. Available at: https://doi.org/10.1016/j.jfbs.2014.10.003

21. Pablo-Lerchundi, I.; Morales-Alonxo, G.; González-Tirados, R. M. 2015. "Influences of Parental Occupation on Occupational Choices and Professional Values", Journal of Business Research 68(7): 16451649. Available at: https://doi.org/10.1016/j.jbusres.2015.02.011

22. Petrosyan, A. E. 2018. "Regaining the Soul Lost (The Limits of Depersonalization in Organizational Management)", Philosophy of Management: 1-25. Available at: https://doi.org/10.1007/s40926-018-0092-3 23. Petrů, N. 2018. Nástupnická strategie v českých rodinných podnicích. Praha: Vysoká škola finanční a správní, a.s. 
24. PricewaterhouseCoopers. 2012. Celosvětový prĩzkum rodinných firem 2012. Available at: https://anzdoc. com/celosvtovy-przkum-rodinnych-firem-2012.html (cited 22.08.2018).

25. PricewaterhouseCoopers. 2015. CEE Family Business Survey: Family Businesses at a Crossroads. Available at: https://www.pwc.com/hu/hu/kiadvanyok/assets/pdf/cee_family_survey_2015.pdf (cited 22.08.2018).

26. Rydvalová, P.; Karhanová Horynová, E.; Jáč, I.; Valentová, E.; Zbránková, M. 2015. Rodinné podnikání - zdroj rozvoje obcí. Liberec: Technická univerzita v Liberci.

27. Rydvalová, P.; Karhanová Horynová, E.; Zbránková, M. 2016. "Family Business as Source of Municipality Development in the Czech Republic", Amfiteatru Economic 18(41): 168-183.

28. Rydvalová, P.; Antlová, K.; Lamr, M. 2017a. Vztah studentů k podnikání: Celosvětový průzkum GUESSS 2016 z pohledu studentů českých vysokých škol. Liberec: Technická univerzita v Liberci.

29. Rydvalová, P. et al. 2017b. Typologie a hodnocení vitality rodinného podnikání. Liberec: Technická univerzita v Liberci.

30. Stewart, H. 1995 (2008). "A Critique of Instrumental Reason in Economics", Economics and Philosophy 11(1): 57-83.

31. Tajalli, P.; Segal, S. 2018. "Levinas, Weber and a Hybrid Network for Business Ethics", Philosophy of Management: 1-18. Available at: https://doi.org/10.1007/s40926-018-0100-7

32. Zellweger, T.; Sieger, P.; Halter, F. 2011. "Should I Stay or Should I Go? Career Choice Intentions of Students with Family Business Background”, Journal of Business Venturing 26(5): 512-536. Available at: https://doi.org/10.1016/j.jbusvent.2010.04.001

33. Zellweger, T. 2017. Managing the Family Business: Theory and Practice. Cheltenham, UK: Edward Elgar Publishing.

ZUZANA HORČIČKOVÁ, NERIJUS STASIULIS

\title{
Ekonomikos ir vadybos filosofija: jaunimo dalyvavimas šeimos versle ir nacionalinėje ekonomikoje
}

\begin{abstract}
Santrauka
Straipsnio tikslas - suderinti filosofini šeimos, kaip komunitarinio esinio vaidmens individualistiniu principu paremtoje ekonomikoje apmąstymą, ir praktinį tyrimą, kuriuo ịvertinama jaunų žmonių pozicija dẻl ịsitraukimo ị šeimos verslą. Tyrimo respondentai - paskutiniųjų metų vidurinių mokyklų moksleiviai ir trečiosios pakopos profesinio mokymo bei karjeros centrų studentai Libereco regione. Šeima etiniu bei politinès ir ekonominès filosofijos požiūriais traktuojama kaip aplinka, tinkama formuoti ekonominị matymą, kuris neapsiriboja vien tik „ekonomistine“ racionalumo forma, ir kaip gebanti vaidinti reikšmingą vaidmenị gerai veikiančioje valstybės ekonomikoje. Praktinis tyrimas rodo, kad jaunuolio ketinimas dirbti šeimos versle priklauso nuo to, ar jis yra $i$ ji ịtraukiamas jau studijų metu.
\end{abstract}

Raktažodžiai: dalyvavimas, ekonomikos filosofija, etika, jaunuolis, racionalumas, šeimos verslas 